\title{
4555 Bioglass porous scaffolds: structure, composition and bioactivity characterization
}

\author{
ME ABAD-JAVIER - IIMM UMSNH • ibq.mario.abad@outlook.com \\ M CAJERO-JUÁREZ - IIAF UMSNH - cajeromarco@hotmail.com \\ ME CONTRERAS GARCÍA - IIMM UMSNH - eucontre@gmail.com \\ Érkezett: 2016. 11. 02. - Received: 02. 11. 2016. - http://dx.doi.org/10.14382/epitoanyag-jsbcm.2016.22
}

\begin{abstract}
Advanced ceramics development is a promising area in regenerative medicine; although there are different biomaterials with features that make them viable enough, their improvement and optimization is required to produce biomaterials easier to bio assimilate and promote a faster tissue recovery. At this work a nanostructured bioglass based biomimetic scaffold is developed, beginning with the sol-gel synthesis parameters establishment coupled with a spray drying stage. Through X-ray diffraction the crystal $\mathrm{Na}_{6} \mathrm{Ca}_{3} \mathrm{Si}_{6} \mathrm{O}_{18}$ phase was characterized, this phase is common to find in almost every $45 \mathrm{~S} 5$ bioglass different synthesis processes, also a standard of mammalian hydroxyapatite was prepared to be used as a comparative control in determining the bioglass scaffold bioactivity. Three-dimensional structure was characterized by optical and scanning electron microscopy, coupled to a semi-quantitative technique (EDS) to determine the composition of the synthesized biomaterial. Subsequently, simulated body fluid (SBF) was used as an in vitro system, whose composition emulates the ionic blood concentration to evaluate the scaffold bioactivity.

Keywords: Bioglass, bioscaffold, bioactivity, characterization
\end{abstract}

\section{Introduction}

Tissue engineering has emerged as a promising option for organ regeneration after partially or totally lost as an accident result, diseases, aging, among others. Tissue engineering has the potential to solve problems such as short feasibility time of donated tissues and even the donor's shortage [1,2]. A biomaterial is defined as a bioactive compound, able to bind chemically and form links with living tissue or be assimilated into the new tissue formation [3,4], and a bioscaffold is a three-dimensional structure made from a biomaterial, to support and guide cell proliferation. At the same time, in the bioscaffold structure can be incorporated other components able to promote tissue regeneration, such as growth factors or other structure molecules as collagen [1].

The biological activity of bioglass scaffolds is ion release dependent, where calcium, phosphorus and silicon ions can modify osteogenic cells gene expression and vascularization, promoting a higher bone formation rate [3]. Particularly, bioglass bioactivity has been improved by the interconnected porous structure generation, allowing high surface area configurations, favoring their use for bone regeneration and making them candidates for controlled drug release in specific body areas [5-7].

Bone structure consists of several organic and inorganic layers, at the organic fraction can be found collagen, granular proteoglycans, cells and non collagenic proteins [8], while the main inorganic fraction is calcium and hydroxyapatite mineral carbonated, that develops along collagen fibers, forming nanocrystals of $40 \mathrm{~nm}$ long with 10 nanometers wide, generating an inorganic nanocomposite; while a $20-30 \%$ hydroxyapatite fraction, is in amorphous phase for release ions to the blood [7].
ME Abad-Javier

Master of sciences since 2014, post-graduate student in Ceramic Biomaterials, Department of Advanced Ceramics, Metallurgy and Materials Research Institute on the Universidad Michoacana de San Nicolás de Hidalgo. He is specialist in sciences of biofunctionalization and synthesis of ceramic materials, and physicochemical analysis of materials and biomolecules based on structure, chemical properties and quantification. His teaching experience include: introduction to bioassays, technical capacitation and analytical methods design

M Cajero-Juárez Doctor in Genetic and Molecular Biology, Titular C Professor and Researcher at the Animal Biotechnology Laboratory of the IIAF on the Universidad Michoacana de San Nicolás de Hidalgo and National Researcher. Specialized on animal genome Manipulation, gene expression on cells and synthetic biology for gene and protein design

ME CONTRERAS GARCÍA Doctor of Sciences since 2000, Titular C Professor and Researcher at the Ceramic Materials Department of the Metallurgy and Materials Research Institute on the Universidad Michoacana de San Nicolás de Hidalgo since 1988 and Level 2 National Researcher since 2001. Specialized on Ceramic Synthesis and Processing Techniques such as ceramic powder processing via sol-gel and chemical techniques, focused on nanostructured ceramics processing and functional ceramics including: structural ceramics, bioceramics, magnetic ceramics, optoelectronic ceramics, catalytic and photocatalytic ceramics, macro-mesoporous ceramics all of them in bulk and in thin films. She is author and co-author of more than 100 international indexed papers, two book chapters and editor in one. She is member of several scientific societies and regional director of the Mexican Academy of Crystallography.

The bioglass scaffold design in conjunction with cell therapy have offered a broad overview regarding the tissue replacement, although there are some problems to overcome as the production and support of cells in the biological area and the development of interconnected networks in the advanced ceramics area, due to the compatibility donor-recipient and the microenvironment necessary for generating functional tissue, respectively $[9,10]$.

Sol-gel synthesis systems coupled with spray drying techniques make it possible to produce bioglass whose composition and mechanical properties comply with the parameters established by different institutions such as the FDA in the United States. Furthermore, the use of these methodologies allows to design nanoparticles aggregates with controlled porosities, standardized diameters and chemical modifiers as silver or polymers, facilitating the experimental design, analysis and helping to overcome the interconnected scaffold structure [11-14]. Nanostructured materials doping has been useful for improve the structural and functional characteristics [14]. Specifically, antimicrobial activity can be conferred upon a biomaterial after doping with silver or copper through the release of these ions in the organism, antimicrobial mechanisms triggers membrane depolarization or generate SOS stress type in bacteria [15-17], however doping in implants is regulated by the ion lethal dose, plus the generated additional costs. 
In this paper, the goal is to design a bioglass $45 \mathrm{~S} 5$ biomimetic scaffold synthesis process and evaluate their in vitro bioactivity, using this biomaterial as ion source to promote the hydroxyapatite development through the hydrolysiscondensation process on the material surface, employing $\mathrm{X}$ ray Diffraction (XDR), Scanning Electron Microscopy (SEM), Energy-Dispersive X-Ray Spectroscopy (EDS) and Fourier Transform InfraRed Spectroscopy (FTIR).

\section{Materials and Methods}

\subsection{Synthesis}

For bioglass mimetic scaffolds synthesis, aggregates of spherical nanoparticles were prepared from the sol-gel technique coupled a spray drying stage. It started with the bioglass $45 \mathrm{~S} 5$ silver-doped and un-doped synthesis. Bioglass 45S5 was carried out using the sol-gel technique, from an aqueous solution of nitric acid $0.1 \mathrm{M}$ for the tetraethyl orthosilicate hydrolysis, process that took an hour of gentle agitation, then proceeded to add triethyl phosphate, calcium nitrate tetra hydrated, sodium nitrate and silver nitrate (only for the silver-doped bioglass), allowing a 45 minutes agitation period between adding each one, all at room temperature. Ensuring the final ratio of precursors and liquid phase at different concentrations to analyze the structural effect (Table 1).

\begin{tabular}{lcccc} 
System & $\begin{array}{c}\text { Nominal Composition (Wt. \%) } \\
\text { Bioglass }\end{array}$ & Water & (g) & $\mathbf{H}_{2} \mathbf{O}(\mathbf{g})$ \\
\hline BGs1:1 & 50 & 50 & 100 & 100 \\
\hline BGs1:3 & 25 & 75 & 50 & 150 \\
\hline BGs1:6 & 14.28 & 85.71 & 28.56 & 171.42 \\
\hline BGs1:9 & 10 & 90 & 20 & 180 \\
\hline BGs1:12 & 7.69 & 92.307 & 15.38 & 184.614
\end{tabular}

Table 1. Feed solutions composition.

1. táblázat Felhasznált oldatok összetétele.

\subsection{Spray drying}

Prepared solutions doped and un-doped were carried to a spray drying equipment Yamato ADL40 resulting in the nanosized spheres agglomerated synthesis. The feed solution was introduced using a single-phase system, through a peristaltic pump with a $2.45 \mathrm{~mL} / \mathrm{min}$ continuous flow. The feed solution was atomized into droplets using pressurized air at 2 bar $\left(2 \times 10^{5} \mathrm{~Pa}\right)$. The atomized droplets were evaporated through a hot air stream whose temperature was maintained at $180^{\circ} \mathrm{C}$. The dried granules are collected using a cyclone incorporated into the atomizing equipment and dried at room temperature for 24 hours.

\subsection{Heat treatment}

Bioglass samples were heat treated, giving an initial drying at $40{ }^{\circ} \mathrm{C}$ for 24 hours, followed by two calcination stages where the heating rate is $3{ }^{\circ} \mathrm{C} / \mathrm{min}$ reaching $100{ }^{\circ} \mathrm{C}$ at the first plateau for 60 minutes and 500, 600 and $700{ }^{\circ} \mathrm{C}$ at the second stage for 180 minutes, followed by a cooling rate of $3^{\circ} \mathrm{C} / \mathrm{min}$.

\subsection{Bioactivity assay}

The in vitro bioactivity of the bioscaffold obtained was assessed by immerging samples in simulated body fluid (SBF) at $37^{\circ} \mathrm{C}$. The bioscaffold sample sizes were standardized in $5 \times 5$ $\mathrm{mm}$ and placed in plastic containers, ensuring a static position free of light. The SBF solution was changed every 24 hours during the immersion period. The inorganic ion concentrations of SBF were $142 \mathrm{mM} \mathrm{Na}^{+}, 5 \mathrm{mM} \mathrm{K}^{+}, 1 \mathrm{mM} \mathrm{Mg}^{2+}, 1.3 \mathrm{mM} \mathrm{Ca}^{2+}$, $103 \mathrm{mM} \mathrm{Cl}^{-}, 27 \mathrm{mM} \mathrm{HCO}_{3}^{-}, 1 \mathrm{mM} \mathrm{HPO}_{4}{ }^{2-}$ and $0.5 \mathrm{mM} \mathrm{SO}_{4}{ }^{2-}$, only differing the $\mathrm{Cl}^{-}$and $\mathrm{HCO}_{3}^{-}$concentrations to those of human blood plasma, with a $\mathrm{pH}$ of $7.40[18,19]$.

The bioglass samples were collected after 8 days of incubation. The collected samples were washed in deionized water five times to eliminate the SBF, and then dried at $27^{\circ} \mathrm{C}$ for two days and stored in a desiccator.

\subsection{Characterization}

Structural characterization was carried out using a field emission scanning electron microscope JEOL JSM-7600F, where the emission spectrometer energy (EDS) analysis was also performed for chemical composition determination and location in the material surface. For the bioglass' phases determination a XRD D8 ADVANCE BRUKER DAVINCI CuKa radiation equipment was employed. Identification of functional groups was performed with an infrared spectrum analysis system IR TENSOR 27 BRUKER in attenuated transmittance mode.

\section{Results and discussion}

\subsection{Bioglass synthesis}

Fig. 1 shows the different particle diameter distributions obtained using the different systems together with the heat treatments proposed, the aggregates diameter was determined from a dynamic light scattering equipment (90-PLUS / BiMAS). This technique determinate the concentration relation with the diameter obtained, larger diameters obtained in systems whose concentration was higher.

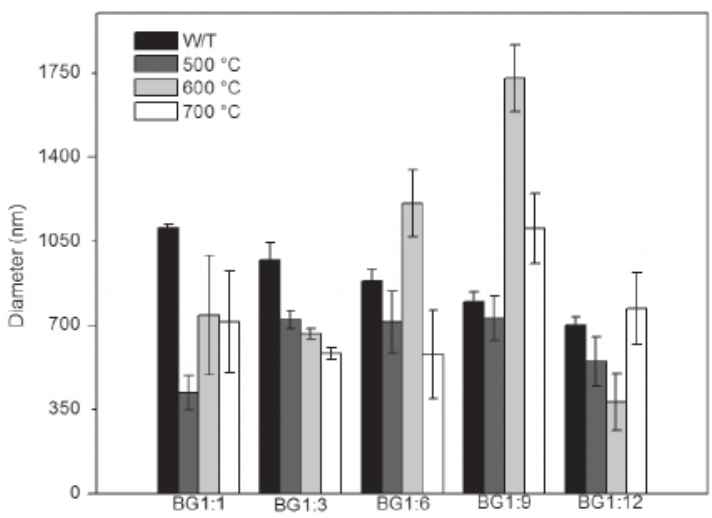

Fig. 1. Bioglass dispersion diameters after different heat treatments.

1. ábra Bioüveg diszperziós átmérők különbözö hőkezeléseket követően.

Aggregate diameter decrease was observed in samples without heat treatment (Fig. $1 \mathrm{~S} / \mathrm{T}$ ) from 1106.1 to $702.1 \mathrm{~nm}$, with an almost linear correspondence, however, this relationship was lost once the thermal treatment took place. While the BGs1:9 deploys wide diameter variability, the BGs1:3 system remains 
stable, with a decrease in particle diameter as the maximum treatment temperature is raised.

Bioglass spheres can be observed in Fig. 2, corresponding to the system BGs1:3 with and without heat treatment, is observed the correct formation of spheres showing the reasonably homogeneous diameters distribution and morphology of bioglass, contrary to previous works which generate irregular and obliquous aggregates even for a similar atomization technique [20], on the other side, another works has been handled the same technique but with different materials, were the spherical bodies formation is only achieved when sintering treatments are employed due to the structure compaction [13].
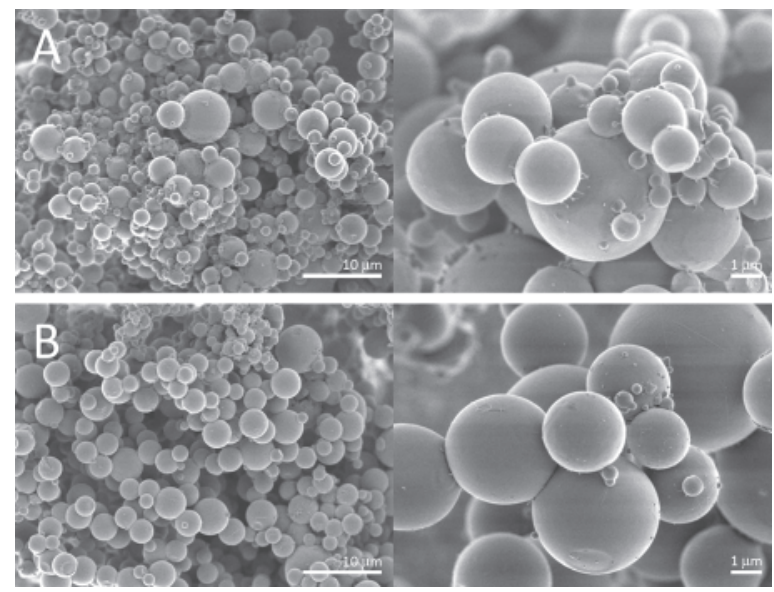

Fig. 2. SEM image of the Bioglass spheres fabricated by the sol-gel/spray draying process. (a) BGs1:3 before heat treatment, (a) BGs1:3 after heat treatment at $700^{\circ} \mathrm{C}$.

2. ábra A szol-gél technikával elóállított bioüveg részecskék elektronmikroszkópos képe. (a) BGs1:3 hökezelés elött (b) BGs1:3 a 700 C hömérsékletü hökezelést követöen.

The BGs1:3 sample whose heat treatment was performed up to $700{ }^{\circ} \mathrm{C}$ exhibited smooth surfaces and a high dispersion, different to another samples; like the BG1:12 where it can be seen joints formation between spheres after sintering, plus some hollow spheres which collapsed after heat treatment and the same BGs1:3 system generating a coral type structure with a certain level of surface roughness. This set of results corresponds with other works, where the bioglass sintering behavior make particle fusion as common, besides the surface roughness loss below the $800{ }^{\circ} \mathrm{C}$ heat treatment, returning the sample roughness and even increasing it, after higher temperature treatments $[21,22]$.

\subsection{Bioglass composition}

EDS analysis determined a bioglass $45 \mathrm{~S} 5$ characteristic spectrum [21] in both systems: the native bioglass (BGs1:3) and the silver-doped bioglass (BGsAg1:3). The presence of contamination by precursors (Fig. $3 a$ and $3 c$ ), generating a signal electron binding energy of $0.392 \mathrm{keV}$ characteristic of nitrogen atoms founded in both bioglasses without heat treatment, indicating this contamination was eliminated during the heat treatment. The contamination is consequence of incomplete nitrate precursors salts removal during the drying stage; through X-ray diffraction (Fig. 4) it was determined this contamination identity as nitratine $\left(\mathrm{NNaO}_{3}\right)$, whose decomposition temperature is $570{ }^{\circ} \mathrm{C}$. Every bioglass sample doped and un-doped have shown the corresponding silicon, calcium, phosphorus, sodium and oxygen peaks (Fig. $3 b$ and $3 d)$, and show the combeite $\left(\mathrm{Na}_{6} \mathrm{Ca}_{3} \mathrm{Si}_{8} \mathrm{O}_{18}\right), \mathrm{SiO}_{2}$ and $\mathrm{CaSiO}_{3}$ phases (Fig. 4) as shown in other synthesis processes where the peaks are associated even with the addition of dopants and after in vitro incubation processes $[23,24]$.

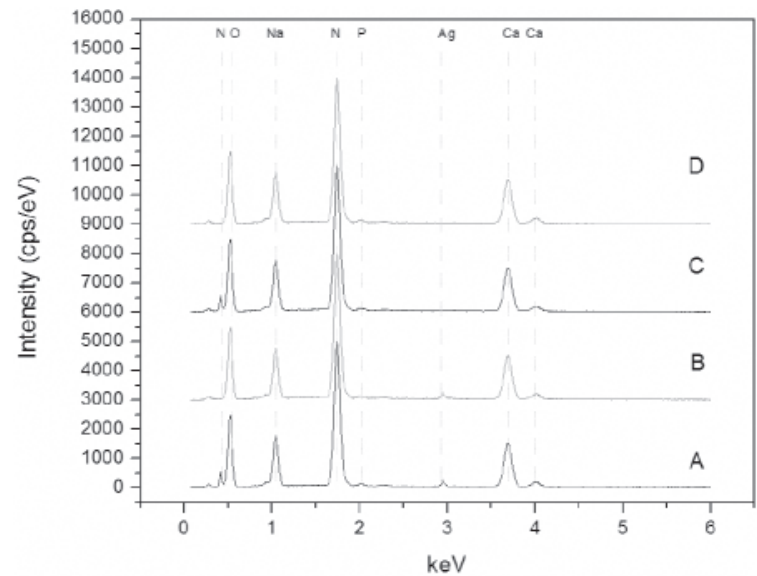

Fig. 3. EDS spectra analysis of bioglass 45S5. (a) Silver-doped bioglass withou heat treatment. (b) Silver-doped bioglass after heat treatment at $700{ }^{\circ} \mathrm{C},(\mathrm{c})$ Bioglass without heat treatment, (d) Bioglass after heat treatment at $700{ }^{\circ} \mathrm{C}$

3. ábra $45 S 5$ bioüveg EDS spektruma. (a) ezüst adalékolt bioüveg hökezelés nélkül, (b) ezüst adalékolt bioüveg $700^{\circ} \mathrm{C}$ hömérsékletü hökezelést követöen, (c) bioüveg hökezelés nélkül, (d) bioüveg $700^{\circ} \mathrm{C}$ hömérsékletü hökezelést követöen.

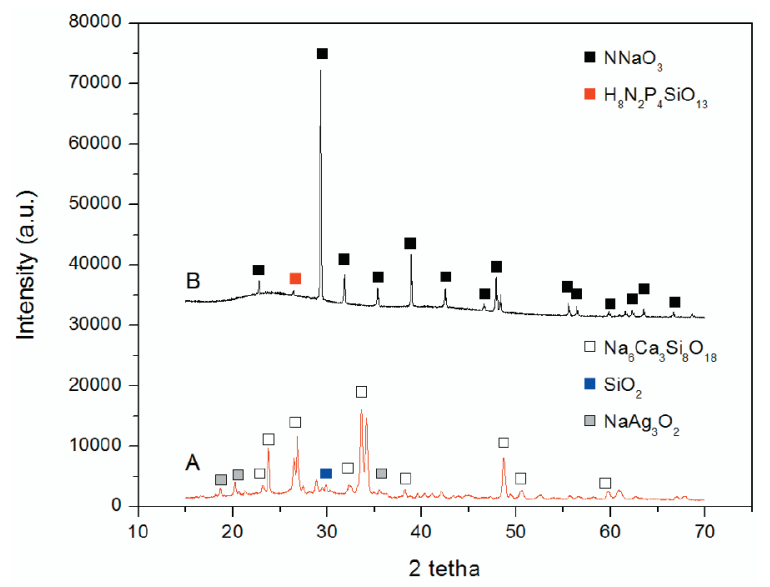

Fig. 4. XDR spectra analysis of silver-doped bioglass 45S5. (a) Silver-doped bioglass after heat treatment at $700{ }^{\circ} \mathrm{C}$, (b) Silver-doped bioglass without heat treatment.

4. ábra Ezüst adalékolt 4555 bioüveg röntgendiffraktogramja. (a) ezüst adalékolt bioüveg $700^{\circ} \mathrm{C}$ hömérsékletü hőkezelést követően, (b) ezüst adalékolt bioüveg hökezelés nélkül.

\subsection{Scaffold preparation}

A preliminary trial for the bioglass scaffold synthesis was made by adding a template agent (polystyrene microspheres) to the sol-gel reaction system before the drying stage, leading to the three-dimensional structure required formation, this bioscaffold have interconnectivity in its three-dimensional structure (Fig. 5), where the porogen and precursors condensation processes form collars and pores of different thickness and size, allowing interconnectivity through it. In the macro structure (Fig. 5), it is able to see spongy bone physical 
similarity, with large enough pores to contain biological structure, where the larger pores are about 500 micrometers, while there is a population of smaller pores with different diameters $[25,26]$.

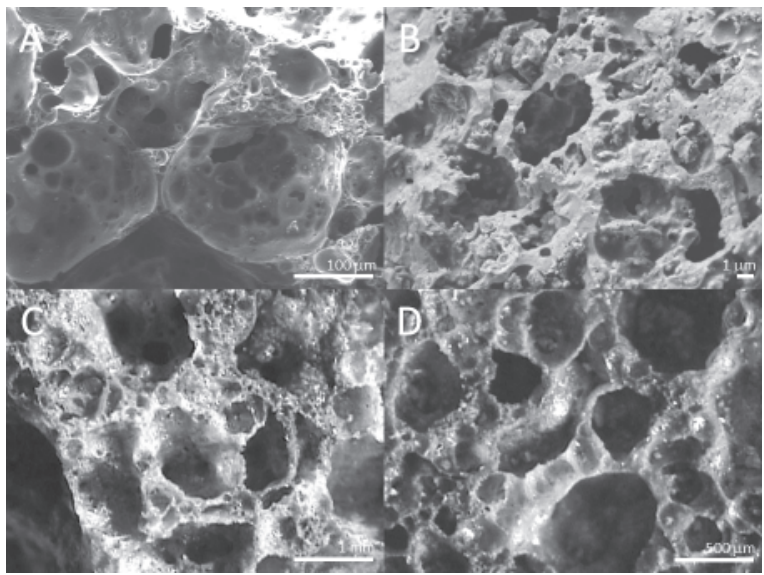

Fig. 5. SEM images of the bioglass scaffold at different magnifications. (a) $250 \times$, (b) $5000 \times,(c) 8 \times$, (d) $16 \times$.

5. ábra Bioüveg elektronmikroszkópos felvételei különböző nagyitás mellett. (a) 250×, (b) $5000 \times$, (c) $8 \times$, (d) $16 \times$

\subsection{Bioactivity}

A bioglass scaffold group of samples were incubated for 8 days in simulated body fluid, these samples were incubated at $37^{\circ} \mathrm{C}$ statically, in total absence of light. The simulated body fluid was changed every 24 hours and then washed three times with distilled water, dried at room temperature and analyzed by X-Ray Diffraction (Fig. 6) and infrared transmittance spectrum (Fig. 7).

In the bioglass scaffolds infrared analysis (Fig. 6) a gradual reduction of the $\mathrm{Si}-\mathrm{O}-\mathrm{Si}$ peaks can be registered, while the higher peak shifts to a value of $1034 \mathrm{~cm}^{-1}$ which corresponds to the phosphate calcium groups that builds up the hydroxyapatite structure showing the in vitro system effect has over the material to facilitate hydroxyapatite formation, the structural change can be observed at the eight day when the spectrum is virtually identical to the hydroxyapatite control, excepting the position corresponding of the $\mathrm{Si}-\mathrm{O}-\mathrm{Si}$ at position $484 \mathrm{~cm}^{-1}$ band indicating there is still a silicon fraction in the scaffold

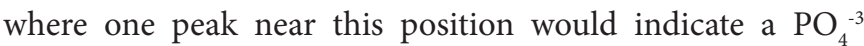
functional group [27].

XDR pattern of the bioscaffold silver-doped sintered at $700{ }^{\circ} \mathrm{C}$ is shown in Fig. $7 a$ intensity and location of the peaks was matched to the combeite pattern, indicating the correct formation of the crystalline phase [23], also the XRD diffraction analysis of the bioscaffold after immersion in SBF for 8 days is shown on Fig. $7 b$ displaying the presence of new peaks correspondent to the hydroxyapatite phase, as evidence of the transition of the combeite phase to an amorphous phase and the presence of cristobalite $\left(\mathrm{SiO}_{2}\right)$, a secondary product of the hydroxyapatite condensation. As bioactivity control the hydroxyapatite pattern shown on Fig. $7 c$ show the peaks necessary to verify the hydroxyapatite presence on the bioscaffold analyzed, matching in at least 5 peaks.



Fig. 6. XDR patterns of $45 S 5$ bioglass bioactivity assay treatment in SBF. (a) bioglass control, (b) bioglass scaffold after 8 days incubation collagen, (c) hydroxyapatite control.

6. ábra 45 S5 bioüveg röntgendiffraktogramja; bioaktivitás szintetikus plazmafolyadékban. (a) bioüveg kontroll, (b) bioüveg implantátumváz 8 napos kollagén inkubációt követően, (c) hidroxiapatit kontroll.

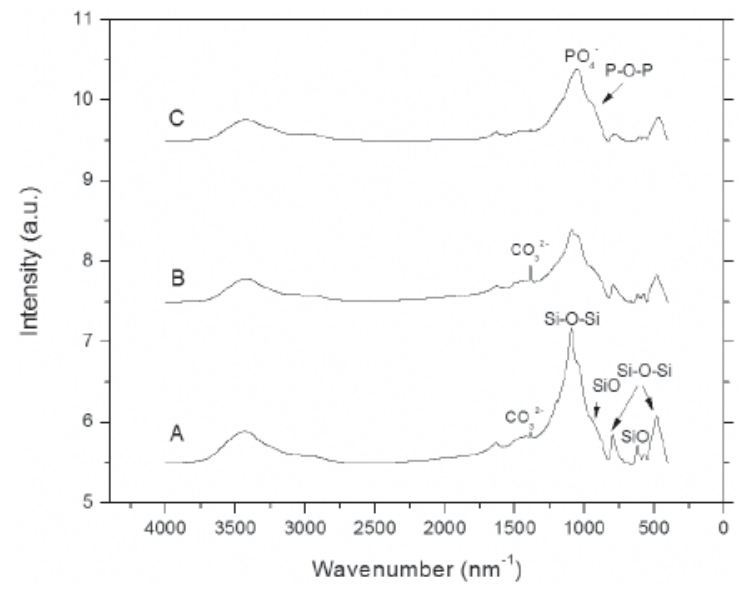

Fig. 7. FTIR spectra of 4555 bioglass bioactivity assay treatment in SBF. (a) bioglass control, (b) bioglass scaffold after 8 days incubation collagen, (c) hydroxyapatite control.

7. ábra 45 S5 bioüveg FTIR spektruma; bioaktivitás szintetikus plazmafolyadékban. (a) bioüveg kontroll, (b) bioüveg implantátumváz 8 napos kollagén inkubációt követöen, (c) hidroxiapatit kontroll.

\section{Conclusions}

It has been synthesized and designed an efficient bioscaffold which bioactivity is enough to produce the bone mineral phase in only eight days using an in vitro system.

We have determined the best synthesis conditions to produce bioglass microspheres to be used as bioscaffold precursors, designing a production process able to mimic the three dimensional spongy bone structure, make it able to provide a physiological type environment to promote vascularization.

\section{Acknowledgments}

This research was funded by UMSNH (Universidad Michoacana de San Nicolás de Hidalgo, México) and CICCONACyT (Consejo Nacional de Ciencia y Tecnología, México), Abad-Javier, M.E. received a doctoral grant from CONACyT. 


\section{References}

[1] Rahamana, M. N. - Day, D. E. - Bal, B. S. - Fu, Q. - Jung, S. B. - Bonewald, L. F. - Tomsia, A. P. (2011): Bioactive glass in tissue engineering. Acta Biomater. Vol. 7, Num. 6, June 2011, pp. 2355-2373, http://dx.doi.org/10.1016/j.actbio.2011.03.016

[2] Langer, R. - Vacanti, J. P. (1993): Tissue engineering. Science. Vol. 260, Num. 5110, May 1993, pp. 920-926, http://dx.doi.org/10.1126/science.8493529

[3] Dawson, E. - Mapili, G. - Erickson, K. - Taqvi, S. - Soy, K. (2008): Biomaterials for stem differentiation. Adv drug deliver Rev. Vol. 60, Num. 2, Jan 2008, pp. 215-228, http://dx.doi.org/10.1016/j.addr.2007.08.037

[4] Jones, J. R. (2009): New trends in bioactive scaffolds: The importance of nanostructure. J Eur Ceram Soc. Vol. 29, Num. 7, April 2009, pp. 12751281, http://dx.doi.org/10.1016/j.jeurceramsoc.2008.08.003

[5] Yun, H. S. - Park, J. W. - Kim, S. H. - Kim, Y. J. - Janq, J. H. (2011): Effect of the pore structure of bioactive balls on biocompatibility in vitro and in vivo. Acta Biomater. Vol. 7, Num. 6, June 2011, pp. 2651-2660, http://dx.doi.org/10.1016/j.actbio.2011.02.014

[6] Yun, H. S. - Kim, S. E. - Hyeon, Y. T. (2007): Design and preparation of bioactive glasses with hierarchical pore networks. Chem Commun. Vol. 7, Num. 21, June 2007, pp. 2139-2141, http://dx.doi.org/10.1039/b702103h

[7] Rho, J. Y. - Kuhn-Spearing, L. - Zioupos, P. (1998): Mechanical Properties and the Hierarchical Structure of Bone. Chem Commun. Vol. 20, Num. 2, March 1998, pp. 92-102, http://dx.doi.org/10.1016/S1350-4533(98)00007-1

[8] Clarke, B. (2008): Normal Bone Anatomy and Physiology. Clin J Am Soc Nephrol. Vol. 3, Num. Suppl. 3, November 2008, pp. 131-139, http://dx.doi.org/10.2215/CJN.04151206

[9] Mimeault, M. - Batra, S. K. (2006): Concise review: recent advances on the significance of stem cells in tissue regeneration and cancer therapies. Stem Cells. Vol. 24, Num. 11, November 2006, pp. 2319-2345, http://dx.doi.org/10.1634/stemcells.2006-0066

[10] Garreta, E. - Gasset, D. - Semino, C. (2007): Fabrication of a threedimensional nanostructured biomaterial for tissue ingenieering of bone. Journal of Biomolecular Engineering. Vol. 24, Num. 1, February 2007, pp. 75-80, http://dx.doi.org/10.1016/j.bioeng.2006.05.017

[11] Balamurugan, A. - Balossier, G. - Laurent-Maquin, D. - Pina, S. - Rebelo, A. H. S. - Faure, J. - Ferreira, J. M. F. (2008): An in vitro biological and anti-bacterial study on a sol-gel derived silver-incorporated bioglass system. Dental Materials. Vol. 24, Num. 10, October 2008, pp. 343-351, http://dx.doi.org/10.1016/j.dental.2008.02.015

[12] Vehring, R. (2008): Pharmaceutical Particle Engineering via Spray Drying. Pharmaceut Res. Vol. 25, Num. 5, May 2008, pp. 999-1022, http://dx.doi.org/10.1007/s11095-007-9475-1

[13] Lukowiak, A. - Lao, J. - Lacroix, J. - Nedelec, J. M. (2013): Bioactive glass nanoparticles obtained through sol-gel chemistry. Chem Commun. Vol. 49, Num. 59, July 2013, pp. 6620-6622, http://dx.doi.org/10.1039/c3cc00003f

[14] Kim, J. - Wilhelm, O. - Pratsinis, S. E. (2001): Packaging of Sol-Gel-Made Porous Nanostructured Titania Particles by Spray Drying. J Am Ceram Soc. Vol. 84, Num. 12, December 2001, pp. 2802-2808, http://dx.doi.org/10.1111/j.1151-2916.2001.tb01097.x

[15] Dongwei, W. - Wuyong, S. - Weiping, Q. - Yongzhong, Y. - Xiaoyuan, M. (2009): The synthesis of chitosan-based silver nanoparticles and their antibacterial activity. Carbohyd Res. Vol. 344, Num. 17, November 2009, pp. 2375-2383, http://dx.doi.org/10.1016/j.carres.2009.09.001

[16] Arce, J. M. - Tatay, A. - Luna, M. L. - Boix, Y. S. - Deltell, J. G. - Barberá, E. G. - Heras, J. B. - Serrano, M. G. (2011): In Vitro Study of the Antimicrobial Properties of a Silver Ion-Releasing Polyurethane Foam. Spanish surgery. Vol. 89, Num. 8, October 2011, pp. 532-538, http://dx.doi.org/10.1016/j.ciresp.2011.02.015

[17] Chatterjee, A. K. - Chakraborty, R. - Basu, T. (2014): Mechanism of antibacterial activity of copper nanoparticles. Nanotechnology. Vol. 25, Num. 13, April 2014, pp. 1-12, http://dx.doi.org/10.1088/0957-4484/25/13/135101

[18] Kokubo, T. - Hushitani, H. - Ohtsuki, C. - Sakka, S. - Yamamuro, T. (1992): Chemical reaction of bioactive glass and glass-ceramics with a simulated body fluid. J Mater Sci Mater Med. Vol. 3, Num. 2, March 1992, pp. 79-83, http://dx.doi.org/10.1007/BF00705272
[19] Kokubo, T. - Takadama, H. (2006): How useful is SBF in predicting in vivo bone bioactivity? Biomaterials. Vol. 27, Num. 15, May 2006, pp. 2907 2915, http://dx.doi.org/10.1016/j.biomaterials.2006.01.017

[20] Vargas, G. E. - Mesones, R. V. - Bretcanu, O. - López, J. M. - Boccaccini, A. R. - Gorustovich, A. (2009): Biocompatibility and bone mineralization potencial 45s5 Bioglass-derived glass-ceramic scaffolds in chick embryos. Acta biomater. Vol. 5, Num. 1, January 2009, pp. 374-380, http://dx.doi.org/10.1016/j.actbio.2008.07.016

[21] Handel, M. - Hammer, T. R. - Nooeaid, P. - Boccaccini, A. R. - Hoefer, D. (2013): 45s5-Bioglass-Based 3D-Scaffolds Seeded with Human Adipose Tissue-Derived Stem Cells Induce In Vivo vascularization in the CAM Angiogenesis Assay. Tissue Engineering. Vol. 19, Num. 23-24, December 2013, pp. 2703-2712, http://dx.doi.org/10.1089/ten.tea.2012.0707

[22] Lefebvre, L. - Chevalier, J. - Gremillard, L. - Zenati, R. - Thollet, G. Bernache-Assolant, D. - Govin, A. (2007): Structural transformations of bioactive glass $45 \mathrm{~S} 5$ whith thermal treatments. Acta Biomater. Vol. 55, Num. 10, June 2007, pp. 3305-3313,

http://dx.doi.org/10.1016/j.actamat.2007.01.029

[23] Adams, L. A. - Essien, E. R. - Shaibu, R. O. - Oki, A. (2013): Sol-Gel Synthesis of $\mathrm{SiO} 2-\mathrm{CaO}-\mathrm{Na} 2 \mathrm{O}-\mathrm{P} 2 \mathrm{O} 5$ Bioactive Glass Ceramic from Sodium Metasilicate. New Journal of Glass and Ceramics. Vol. 3, Num. 1, January 2013, pp. 11-15, http://dx.doi.org/10.4236/njgc.2013.31003

[24] Verne, E. - Di Nunzio, S. - Bosetti, M. - Appendino, P. - Brovarone, C. V. - Maina, G. - Cannas, M. (2005): Surface characterization of silver-doped bioactive glass. Biomaterials. Vol. 26, Num. 25, September 2005, pp. 5111 5119, http://dx.doi.org/10.1016/j.biomaterials.2005.01.038

[25] Chen, Q. Z. - Thompson, I. D. - Boccaccini, A. R. (2006): 45s5 Bioglassderived glass-ceramic scaffolds for bone tissue engineering. Biomaterials. Vol. 27, Num. 11, April 2006, pp. 2414-2425, http://dx.doi.org/10.1016/j.biomaterials.2005.11.025

[26] Eqtesadi, S. - Motealleh, A. - Miranda, P. - Pajares, A. - Lemos, A. Ferreira, J. M. F. (2014): Robocasting of 45S5 bioactive glass Scaffolds for bone tissue engineering. J Eur Ceram Soc. Vol. 34, Num. 1, January 2004, pp. 107-118, http://dx.doi.org/10.1016/j.jeurceramsoc.2013.08.003

[27] Stanciu, G. A. - Sandulescu, I. - Savu, B. - Stanciu, S. G. - Paraskevopoulos, K. M. - Chatzistavrou, X. - Kontonasaki, E. - Koidis, P. (2007): Investigation of the Hydroxyapatite Growth on Bioactive Glass Surface. Journal of Biomedical \& Pharmaceutical Engineering. Vol. 1, Num. 1, 1 pp 34-39.

$\underline{\text { Ref.: }}$

ME Abad-Javier - M Cajero-Juárez - Contreras García, ME: 45 S5 Bioglass porous scaffolds: structure, composition and bioactivity characterization

Építőanyag - Journal of Silicate Based and Composite Materials, Vol. 68, No. 3 (2016), 124-128. p.

http://dx.doi.org/10.14382/epitoanyag-jsbcm.2016.22

45S5 Bioüveg porózus implantátumvázak: szerkezet, összetétel és bioaktivitás

A regeneratív gyógyászatban elôremutató eredményeket értek el kerámia kompozitok fejlesztése során; amellett, hogy különféle bio-anyagokat sikerült kifejleszteni, lehetôvé vált kedvezôbb bio asszimilációs tulajdonságú anyagok alkalmazása, amelyeken a szövet regenerálódás gyorsabb. A cikk nano-szerkezetú bioüveg alapanyagú biomimetikus implantátumvázak anyagának fejlesztését mutatja be, amelyeket szol-gél technológiával állítottak eló. A kristályos $\mathrm{Na}_{6} \mathrm{Ca}_{3} \mathrm{Si}_{6} \mathrm{O}_{18}$ fázis vizsgálata röntgendiffrakciós eljárással történt. Ez a fázis megtalálható majdnem minden 4555 bioüvegben, függetlenül azok gyártási eljárásától. A termék bioaktivitását összehasonlították emlốs hidroxiapatit bioaktivitásával. A három dimenziós szerkezet vizsgálata optikai mikroszkópos és pásztázó elektronmikroszkópos vizsgálattal történt, kiegészítve félkvantitatív eljárással (EDS). Az in vitro bioaktivitási vizsgálatokat szintetikus plazmafolyadékban végezték, amelynek összetétele hasonló volt a vér ionos összetételéhez.

Kulcsszavak: Bioüveg, bio implantátum váz, bioaktivitás, jellemzôk 